\title{
Model of Forensic Hydrography
}

\section{Josip Kasuma , Marko Pilića , Nebojša Jovanovićb, Harrison Pienaar ${ }^{\mathrm{b}}$}

Forensic science plays a vital role in the work of judicial bodies. The contents, knowledge, and specialized expertise permit the identification of facts essential to law enforcement and judicial disputes. Hydrography is an applied science that concerns the physical description, measurement, mapping, and predictions of marine and terrestrial water features (ocean, seas, rivers, lakes, and coastal areas). A variety of economic and other activities take place in water resources. In order to reduce incidents and losses, it is extremely important to operate with accurate hydrographic data. In addition to its standard analytical role, forensics may serve in the prevention of adverse events and /or conditions. This paper aims at contributing towards the development of the new multidisciplinary field of forensic hydrography. The specific objectives are to provide a framework for the establishment of a model of forensic hydrography. A model of forensic hydrography is developed based on eleven modules (elements) relevant to fields in the marine, terrestrial, and coastal water domains. Forensic hydrography should serve the analysis and prevention of unwanted and other events and conditions to increase safety of navigation and security of water resources and in support of all other marine activities, including economic development, defence, safety and security, scientific research, social cohesion, as well as environmental management and conservation.

\footnotetext{
a. University Department of Forensic Sciences, Split, Croatia

e-mail: jkasum@unist.hr

b. Council for Scientific and Industrial Research, Stellenbosch, South Africa

e-mail: njovanovic@csir.co.za

doi: 10.7225/toms.v08.n02.010

This work is licensed under (cc) BY
}

\author{
KEY WORDS \\ $\sim$ Water resources \\ $\sim$ Security \\ $\sim$ Forensic hydrography \\ $\sim$ Environment \\ $\sim$ Navigation \\ $\sim$ Infrastructure \\ $\sim$ Artificial intelligence
}

\section{INTRODUCTION}

Forensic science plays a vital role in the work of judicial bodies. The contents, knowledge, and specialized expertise permit the identification of facts essential to law enforcement and judicial disputes. Forensic hydrography, as a new discipline of forensic science, has a huge potential in establishing itself as a 'must-have' tool in preserving our planet's most important resources.

Seas, rivers, and lakes are natural resources of the Earth. They occupy about $71 \%$ of the Earth's surface area, whereas continents and islands occupy the remaining $29 \%$. Therefore, scientific studies of the sea, rivers, and lakes are considered important for humankind. As an applied science, hydrography is one of the sciences that deals with the exploration of the sea, rivers, and lakes (Kasum, Žanić Mikuličić, Kolić, 2018). According to the International Hydrographic Organization - IHO: 'hydrography is the branch of applied sciences which deals with the measurement and description of the physical features of oceans, seas, coastal areas, lakes and rivers, as well as with the prediction of their change over time, for the primary purpose of safety of navigation and in support of all other marine activities, including economic development, security and defence, scientific research, and environmental protection. In addition to supporting safe and efficient navigation of ships, hydrography underpins almost every other activity associated with the sea, 
including: resource exploitation - fishing, minerals, environmental protection and management, maritime boundary delimitation, national marine spatial data infrastructures, recreational boating, maritime defence and security, tsunami flood and inundation modelling, coastal zone management, tourism and marine science'. Hydrography includes measurements and description of the physical characteristics of the water mass of the oceans, seas, lakes, rivers, and coastal areas. It also deals with predictions of possible changes in the physical characteristics over time in order to improve the safety of navigation. A variety of economic and other activities take place in water resources, such as commercial and non-commercial fisheries or even more environmentally unfriendly activities, like oil and gas exploits. According to the annual report of the European Maritime Safety Agency (2018), the number of losses (financial, technical, fatalities...) and incidents in the maritime industry is steadily growing. Therefore, to reduce some of the losses and incidents, it is extremely important to operate with accurate hydrographic data.

It can be argued that water resources are inextricably linked to diverse human activities defined by the terms: risk, accident, threat, catastrophe, safety, security, navigation, defence, degree of safety, degree of safety protection, degree of safety of navigation, environment, environmental protection, environmental pollution, optimal environmental management, coastal zone management, sustainable fishing, sea exploitation, underwater exploitation, human health, and more. In the maritime and water sector, shipping companies and other business entities play an important role in various business processes. Among other activities, they are involved in the transportation of significant quantities of various cargoes worldwide. Offshore engineering and the exploitation of offshore resources are in constant high dynamic technological development and economic growth. Part of the diverse organizational entities and / or entities of the maritime economy have the characteristics of critical infrastructure. They are exposed to a variety of threats. Accidents occur in the implementation of these activities. For example, in maritime affairs, according to the European Maritime Safety Agency (EMSA), $71 \%$ of maritime accidents occur due to human impact and attributed human error (The European Maritime Safety Agency, 2018). For the most part, these disasters cause consequent pollution of water resources. People in business processes and regulatory environments make decisions based on the available information. The more accurate, reliable and relevant the information, the easier it is to make well-informed decisions and reduce the number of potentially harmful events. Thus, the role of hydrography can be noticed in reducing uncertainty and / or improving the accuracy of information relevant to different processes, for example in the maritime economy (Kasum, Žanić Mikuličić, Kolić, 2018). By utilising hydrographic procedures in the implementation of authorised hydrographic organisations, hydrography provides a sufficient information base in the information part of navigation safety in order to successfully carry out navigation and economic processes at sea and / or at the seabed (Kasum, Gretić, Fredotović Božić, 2010). Therefore, in the area of water resources care, navigation safety, security, defence and management, new methods should be developed to maintain and / or achieve the desired, or sustainable status of water resources.

It is suggested that forensic hydrography could play an important role in this. A basic definition of forensic hydrography is therefore suggested as a multidisciplinary science that uses scientific knowledge and information to determine facts essential to decisions regarding hydrography. Forensic hydrography should serve the analysis and prevention of unwanted and other events and conditions with the purpose of increasing the degree of safety for navigation and security of water resources and in support of all other marine activities, including economic development, security and defence, scientific research, and environmental protection.

This paper aims at contributing to the development of this new multidisciplinary field of forensic hydrography. The specific objectives are to provide a framework for the establishment of model of forensic hydrography and to develop a unique modular system in forensic hydrography.

\section{MODEL OF FORENSIC HYDROGRAPHY}

A forensic hydrography model was developed with a systematic approach using a general system theory. The system can be considered as a whole, interconnected with a general function. To understand a system, it is crucial to comprehend its subsystems or modules and connections between them. Application of that is found in general system theory (Bertalanffy, 1968). The breakdown into modules and fundamental interfaces presents a general model. The general model of forensic hydrography is shown in Figure 1.

The reasons for the development of forensic hydrography can be assessed by a thorough analysis of the subsystems at the current level of generalization, providing an insight into the processes and / or elements of the contained subsystems.

Forensic hydrography subsystems are related to:

- (P1) safety of navigation and security

- (P2) analysis of conditions and prevention in water resources

- (P3) business data infrastructure,

- (P4) environmental protection of water resources,

- (P5) environmental management,

- (P6) coastal zone management,

- (P7) offshore engineering, water resources, and fishing,

- (P8) public health,

- (P9) critical infrastructures and water resources, 


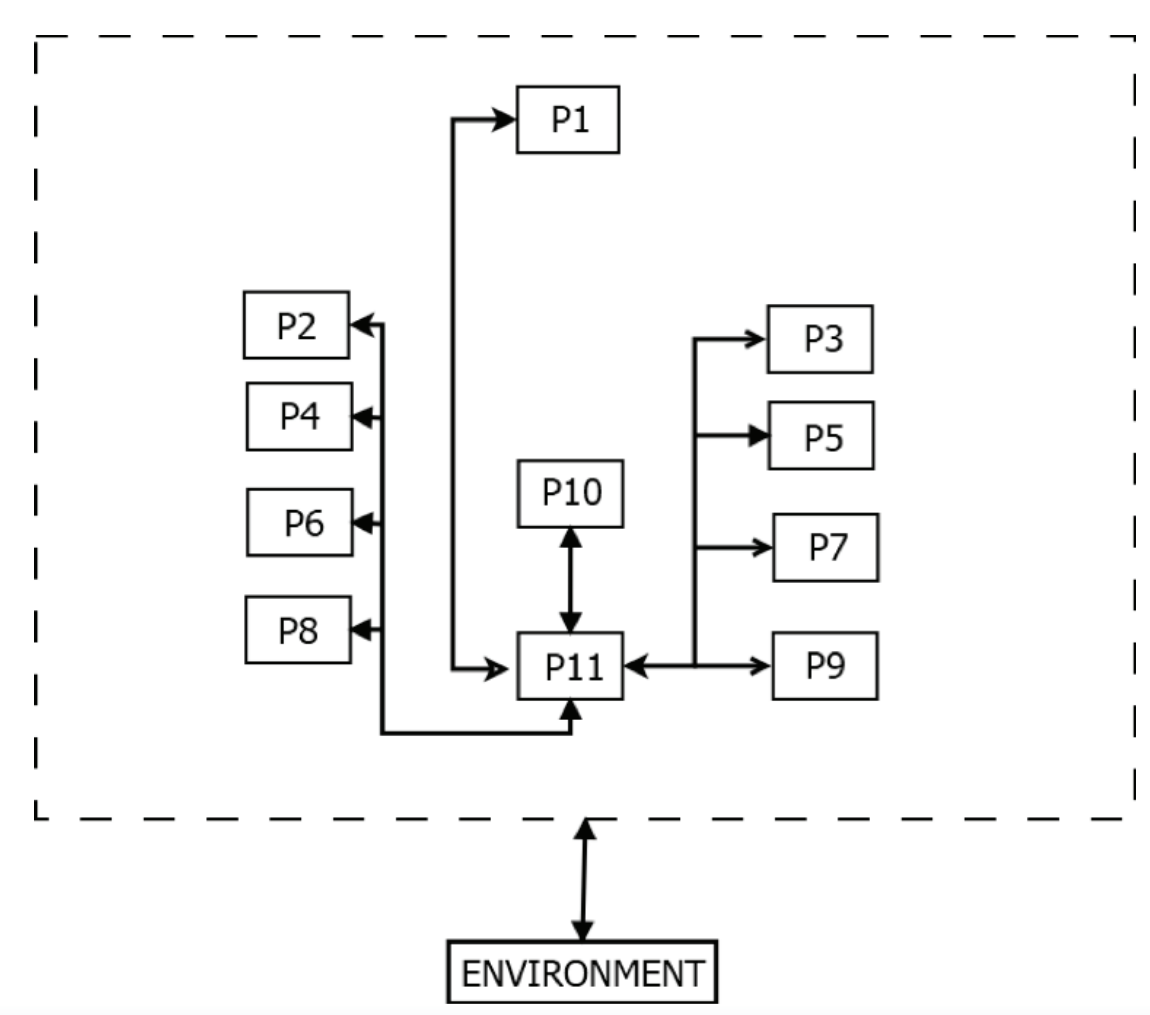

Figure 1.

Forensic hydrography model.

- (P10) e-navigation and new elements of system development and

- $\quad$ (P11) hydrographic cadastre.

\section{(P1) Safety of navigation and security}

Navigation safety and security are largely related to critical infrastructures. Therefore, additional attention is required in their implementation. According to legislation in the Republic of Croatia - EU, the safety of navigation enables the fulfilment of the basic conditions regarding maritime facilities, inland navigation vessels, and territorial seas of the Republic of Croatia, its ports, crews, waterways, navigation process, and pilotage service at sea. In order to satisfy the basic conditions regarding the safety of navigation in the Republic of Croatia, 1035 different navigation safety facilities are operational. In the Republic of Croatia, the business entity "Plovput" manages business processes of maintaining maritime facilities and its headquarters is in Split (Ministry of the sea, transportation and infrastructure of the Republic of Croatia, 2019). It is also necessary to emphasise the importance of the Hydrographic Institute of the Republic of Croatia as a public institution for conducting the hydrographic activity of interest to the Republic of Croatia, operating under the Act of Croatian hydrographic activity. By following the legislation, protection in navigation processes refers to merchant ships and ports open to international traffic. Thus, the legislation regulates the security protection of merchant ships of Croatian nationality and the obligations of various state administration bodies involved in navigation and other processes in connection with maritime economy. The obligations of port authorities, various companies, legal and natural persons have been defined. Special purpose ports also specify the obligations of the concession holder. Port and ship security measures have been developed, as well as models for dealing with security threats (Law on the Safety of Maritime Ships and Ports of Republic of Croatia, 2004). Certainly, a complete transport system, including maritime and water transport, is a critical infrastructure (Law on critical infrastructures, 2013). It can be concluded that in the safety of navigation and protection in all the processes of control, measurement, management, etc., crucial information is the one regarding Maritime Safety Information (MSI). What can be improved partly lies in the domain of forensic hydrography with its insights based on the information gathered, assisted in forensic research in connection with the analysis or prevention of adverse events through a forensic approach. Thus, forensic hydrography serves to significantly increase the degree of safety of navigation and protection of water resources through the methods and tools of forensics. 
(P2) Analysis of conditions and protection in water resources

In today's scientific and other research, an interdisciplinary, multidisciplinary and transdisciplinary approach is increasingly applied. Natural and other disasters, accidents, adverse events, and catastrophic pollution, particularly of water resources, unfortunately occur on an almost daily basis. The knowledge of particular scientific fields is being increasingly used in interdisciplinary, multidisciplinary, and transdisciplinary research. Forensic hydrography is fundamentally interdisciplinary, multidisciplinary, and transdisciplinary, and it is considered to be justified to use it in process analysis and prevention of adverse events in connection with water resources. For example, petroleum pollution in the Gulf of Mexico that caused great concern within neighbouring countries of Mexico (Botello, Villanueva, Diaz, 1997), as one of the biggest pollution of water resources ever, is presumed to have been avoidedable via early detection in real-time using sensors and its dedicated software.

\section{(P3) - Business data infrastructure}

The concept of Spatial Data Infrastructure (SDI) refers to different arrangements and agreements between various governmental and other bodies. In order to facilitate the availability of spatial data in SDI, various policies and technological bases can be included as a system, such as exchange of data, use of databases, etc. As a system, SDI enables data recognition. Once the SDI data is identified, it is possible to evaluate it, for example using geodetic information system as a platform for identification and evaluation. Methods of applying SDI in administrative and other government bodies, science, profession, and economy are also determined (Spatial Data Infrastructure Cookbookv2.0, 2004). Therefore, in enriching the content of SDI, forensic hydrography assumes its role, by providing additional information with maximum accuracy (maritime safety information, bathymetric information, hydrographic information). Such information represents the basis for logical analysis and valid conclusions.

\section{(P4) - Environmental protection of water resources}

Life on Earth has become more and more endangered in the last few decades compared to historic trends due to anthropogenic impacts. Certainly, the technical and technological development of humanity facilitates the production processes. However, it is resulting in an increased pollution of water resources. Their pollution decreases the quality of life. Various policies and implementation of mitigation measures have to be considered to protect water resources. The purpose of these policies is to safeguard a long-term protection and conservation of natural resources. Minimum efforts are to maintain the current status and reduce further hazards to water resources. Water resources such as the sea, rivers, lakes, glaciers, etc. are exposed to significant and permanent pollution. A systematic approach in as many areas of water resources as possible is required to determine baseline states in order to monitor and improve the current situation. Forensic hydrography certainly finds its application in terms of records, prevention, and analysis (Definiton on environmental protection).

In terms of environmental protection of water resources, forensic hydrography is tightly linked with the accompanying research fields of forensic hydrology and forensic hydrogeology (Leonhart, Hargis 2005; Ramirez, Herrera 2016; Lischeid, Balla, et.al., 2017; Witte, Zaadnoordijk, Buyse, 2019). Application of these research areas to forensic hydrography can be found primarily in identifying potential pollution sources, tracing pathways, delineation of pollution and protection zones, characterising bio-geochemical reactions, quantification of concentrations and loads of pollution in coastal areas from rivers, with associated impacts on estuarine and marine ecosystems. The second major application is to quantify and mitigate the effects of extreme weather events such as floods and droughts, and their impacts on reshaping coastal and marine landscapes. One of the most interesting land processes is the mobilisation, transport, and deposition of sediments because this affects the hydrography of coastal areas. River sediments can be deposited in river harbours that may result in unwanted siltation of waterways and dredging requirements (Van Schijndel, Kranenburg, 1998). River sediments are often carriers of other forms of pollutants that may impact marine life. Besides, sediment accumulation due to anthropogenic activities on land may cause unnatural impacts, such as the closure of estuaries, modification of ocean/ sea currents, and coastal erosion (Wang, Andutta, 2013).

\section{(P5) Environmental management}

There are on-going activities in the world to protect the natural environment. As a result, the field of environmental management is developing. Environmental management refers to scientific and professional research related to habitat conservation, hazard control, monitoring, use, and conservation of various natural resources. Scientists and experts from different scientific fields and branches of science are involved in scientific and professional environmental research (Voulvoulis, Burgman, 2019). Besides biophysical sciences, important components of environmental management are the socio-economic and governance regulatory aspects. This is why a multidisciplinary approach is used in environmental management.

One of the basic principles and purposes of environmental management is to provide solutions for sustainable development, growth of the economy and job creation, whilst maintaining and conserving environmental goods and services. In order to achieve this balance, various approaches and strategies can be adopted according to the principles of green or circular economy (Ghisellini, Cialani, Ulgiati, 2016), such as the "polluterpays principle", trade-offs that may allow development whilst 
providing reasonable environmental protection etc. Decisions that may affect the biophysical environment are ultimately regulated within national and EU frameworks, such as Law on the Safety of Maritime Ships and Ports of the Republic of Croatia and EMSA.

Forensic hydrography, in particular, due to its interdisciplinary, multidisciplinary, and transdisciplinary nature in terms of records, prevention, and analysis, allows for an improvement in the environmental management process, both through the provision of physical data and evidence and through the application of law and regulatory frameworks.

\section{(P6) Coastal zone management}

Seas, oceans, and other water surfaces occupy approximately $2 / 3$ of Earth's surface. The land is pervaded and surrounded with water resources and this creates an associated coastline. Therefore, a new area of activity called Coastal Zone Management (CZM) was conceptualized a few decades ago. Amongst the various coastal zone management activities, actions, and processes related to environmental, economic, and human activities are coordinated. The implementation of the CZM seeks to restore, develop, conserve, and protect coastal resources (NOAA's Coastal Zone Management). Therefore, forensic hydrography plays an important role in enabling improved coastal zone management, by directly providing maximum accuracy information, thereby improving the quality of conclusions based on logical forensic analysis, primarily in the prevention of adverse events in contact with land with water resources.

Such adverse events may be caused by droughts, floods or extreme atmospheric events (e.g. cyclones, hurricanes) that result in changes of coastal morphology. Sea level rise, in combination with extreme events, may exacerbate the effects on coastal wetlands and erosion, tidal ranges, human settlements, infrastructure, harbours and seawater pathways (Passeri, et. al., 2015). The frequency and intensity of extreme weather events and sea-level rise are predicted to increase due to climatic changes (IPCC, 2014) and this may result in increased hazards in coastal areas. Forensic hydrography can play an important role in coastal infrastructure, business and property insurance disputes (Koerth, Vafeidis, Hinkel, 2017). Seawater intrusion due to exploitation of groundwater resources and land subsidence is also a hazard in coastal areas where forensic hydrography may be essential (Werner, et.al., 2013; Huang, Ji, 2018). Additional secondary effects that may also require the engagement of forensic hydrography may relate to water supply and availability (volumes and water quality) in coastal areas.

\section{(P7) Offshore engineering, water resources, and fishing}

Offshore engineering represents a significant part of the global economy in exploiting natural energy reserves. In economic activity in the water resource, ecological accidents may occur with significant damages to the sea/ocean and coastal ecosystems. It can be argued that humanity's interaction with the sea and with water resources in general, is initially noticeable in fishing. Fishing in seas, oceans, rivers, and lakes may be either a food source or recreational. Due to technical and technological development, fishing is constantly evolving as a form of economic activity. It must be emphasized that over-fishing, as well as non-critical breeding, represent a danger to the survival of certain species of fish and other organisms in the sea and other water resources. In these human economic and sports activities, forensic hydrography certainly finds its place, especially in the analysis of the status and prevention of over-exploitation (Merriam Webster Dictionary, 2019).

\section{(P8) Public health}

The position of forensic hydrography in the public health domain can be assessed through a transparent analysis of the concept of health. Health can be considered as the condition of a person without illness or injury. In today's world, difficult, often dramatic events, naturally or artificially induced, are on the rise. These events include, for example fires, floods, wars, poisonings and more. Such events, often due to the mass and variety of consequences, often produce certain effects on human health and they present additional new challenges for the healthcare systems. For prevention, preliminary preparation, as well as subsequent analysis, forensic hydrography plays its role (Definition of health, 2019).

\section{(P9) Critical infrastructures and water resources}

Various systems of national importance are considered critical infrastructures. Interruption of their proper operation may result in an interruption of the flow of goods or services. If the interruptions present serious consequences, for example in national security, the environment, human health, human life, property, security, the economic stability of the country, and the continued functioning of the state government, then they become part of a critical infrastructure. The Critical Infrastructures Act regulates national (Law on critical infrastructures, 2013) and European critical infrastructures (Council Directive on the identification and designation of European critical infrastructures and the assessment of the need to improve their protection, 2008). The same law defines sectors of national critical infrastructures. Critical infrastructure management is also determined. For this purpose, risk analysis and security planning are made for critical infrastructures, and a security coordinator is appointed. Critical infrastructures related to marine and water resources are also logically linked to forensic hydrography in the sense of the very definition of forensic hydrography, considering that maritime traffic represents a significant part of protecting critical infrastructures (Law on critical infrastructures, 2013). 


\section{(P10) E-navigation and new elements of system development}

This subsystem, within the forensic hydrography system model, predicts the future integration of all unlisted or unrecognized elements essential to the sustainability of the system and the generation of expected output sizes, i.e. results, with the support of artificial intelligence. For example, the E-navigation concept of the International Maritime Organization (IMO) may be classified here. Maritime traffic is defined mostly as an act of business of transportation of goods and as such is highly regulated by IMO. Therefore, using a piece of hydrographic information through e-navigation is essential, and maritime traffic cannot be imagined without hydrography. Using multiple information-based platforms means to integrate all available elements to provide safety and sustainability of maritime traffic.

\section{(P11) Hydrographic cadastre}

World hydrographic activity is determined by the activities of the International Hydrographic Organization (IHO) based in Monaco. Hydrographic activity at a global level brings together knowledge about the sea and other water resources. The organized hydrographic activity contributes towards the valid collection of the most accurate information related to forensic hydrography (Kasum, Žanić Mikuličić, Kolić, 2018; Kasum, Gretić, Fredotović Božić, 2010; Žanić Mikuličić, Kasum, Jugović, 2017). Based on the systematic analysis performed in this paper, it can be concluded that the information (Fh (1), Fh (2),...,Fh (n)), presented in Table 1, constitutes the information set of forensic hydrography $\mathrm{F}$.

$F=\left\{F_{h 1^{\prime}} F_{h 2^{\prime}} \ldots, F_{h n}\right\}$

The information presented in Table 1, depending on the degree of confidentiality, can be used to develop a database and/ or banks of information and / or data, and to classify, quantify, and evaluate data and information.

With such banks and/or databases it is certainly possible to optimally manage information gathering, synthesise information and use it in the prevention of adverse events, assessments of risks and damages, and dispute settlements.

It is also considered logical that forensic hydrography on its own can be built as a separate subsystem of hydrographic activity at the world level, partly supported by artificial intelligence and systematically classified in the activity of hydrographic cadastre of hydrographic organisations.
Table 1.

Forensic hydrography information and / or data.

$\mathbf{F}_{\mathbf{n}}{ }^{1} \quad$ Description

$\mathrm{F}_{\mathrm{h} 1} \quad$ Analysis of past events

$\mathrm{F}_{\mathrm{h} 2} \quad$ Results of analysis of past events

$\mathrm{F}_{\mathrm{h} 3} \quad$ Simulation of events in water resources

$\mathrm{F}_{\mathrm{h} 4} \quad$ SDl information of maximum accuracy

$\mathrm{F}_{\mathrm{h} 5} \quad$ Information on existing processes in environmental management

$\mathrm{F}_{\mathrm{h} 6} \quad$ Data on pollution

$\mathrm{F}_{\mathrm{h} 7} \quad$ CZM information

$\mathrm{F}_{\mathrm{h} 8} \quad$ Results of conducted forensic analysis

$F_{h 9} \quad$ Forensic hydrography information

$\mathrm{F}_{\text {h10 }} \quad$ Maritime cadastre information

$\mathrm{F}_{\mathrm{h} 11} \quad$ Database and banks of data on all available natural and other catastrophes, accidents, adverse events, and catastrophic pollutions

$\mathrm{F}_{\mathrm{h} 12} \quad$ Fishing information

$\mathrm{F}_{\mathrm{h} 13} \quad$ Breeding information within water resources

$\mathrm{F}_{\text {h14 }} \quad$ Information on the state of water resources

$F_{\text {h15 }} \quad$ Health information

$F_{h 16} \quad$ Offshore information

$\mathrm{F}_{\mathrm{h} 17} \quad$ Prevention processes

$\mathrm{F}_{\mathrm{h} 18} \quad$ Processes of action

$\mathrm{F}_{\text {h19 }} \quad$ Information on critical infrastructures

$\mathrm{F}_{\text {h20 }} \quad$ Bathymetric data

$\mathrm{F}_{\text {h21 }} \quad$ Hydrographic data

$F_{\text {h22 }} \quad$ E-navigation system data

$\mathrm{F}_{\text {h23 }} \quad$ Entities on bottom of water resources

$\mathrm{F}_{\mathrm{hn}} \quad$ Others

\section{CONCLUSION}

It can be concluded that, in order to conserve the world's water resources, it is extremely important to contribute towards the development and application of forensic hydrography. Any field of science at some point in time can be considered as a part of forensic science. Forensic hydrography can serve as an analysis and prevention of unwanted and other events and conditions

1. Marking the information and / or data of forensic hydrography. 
with a view to increasing the degree of safety of navigation and security of water resources. It can also support all other marine activities, including economic development, security, and defence, scientific research, and environmental protection. It is also considered beneficial to integrate forensic hydrography into the regular processes of hydrographic organisations, especially through the activity of the hydrographic cadastre. Of course, the realisation of forensic hydrography depends on recognising it and raising awareness of the threat to water resources globally, developing the necessary computer and software support, and educating experts. Capacity building is especially required in determining the state and transition between system states, guided by general system theory, and developing applicable decision algorithms in the forensic hydrography system, as well as applying artificial intelligence systems.

\section{REFERENCES}

Bertalanffy Von, L., 1968. General system theory - foundation, development, applications, George Braziller, New York.

Botello, A.V., Susana Villanueva, F. \& Gilberto Diaz, G., 1997. Petroleum Pollution in the Gulf of Mexico and Caribbean Sea. Reviews of Environmental Contamination and Toxicology, pp.91-118. Available at: http://dx.doi.org/10.1007/978-1-46122302-3_3.

Council Directive, 2019. .... on the identification and designation of European critical infrastructures and the assessment of the need to improve their protection. Available at: https://eur-lex.europa.eu/legal-content/EN/TXT/HTML/?uri=CELEX:32 008L0114\&from=EN, accessed on: July, 2019.

Definiton on environmental protection, 2019. Available at: http://www. businessdictionary.com/definition/environmental-protection.html, accessed on: September, 2019.

Ghisellini, P., Cialani, C. \& Ulgiati, S., 2016. A review on circular economy: the expected transition to a balanced interplay of environmental and economic systems. Journal of Cleaner Production, 114, pp.11-32. Available at: http://dx.doi.org/10.1016/j. jclepro.2015.09.007.

Huang, Y. \& Jin, P., 2017. Impact of human interventions on coastal and marine geological hazards: a review. Bulletin of Engineering Geology and the Environment, 77(3), pp.1081-1090. Available at: http://dx.doi.org/10.1007/s10064-017-1089-1.

IPCC, 2014. Climate Change 2014, Synthesis Report. Contribution of Working Groups I, II and III to the Fifth Assessment Report of the Inter-Governmental Panel on Climate Change. Core Writing Team, Geneva, Switzerland, p.151.

Kasum, J., Gretić, Z., Fredotović, Božić, K., 2010. Traffic and hydrographic survey of inland waterways and sea. Savjetovanje sa međunarodnim učešćem - Transport i savremeni uslovi poslovanja, Travnik, $\mathrm{BiH}$.

Kasum, J., Žanić Mikuličić, J. \& Kolić, V., 2018. Safety Issues, Security and Risk Management in Nautical Tourism. Transactions on Maritime Science, 7(02), pp.184188. Available at: http://dx.doi.org/10.7225/toms.v07.n02.008.

Koerth, J., Vafeidis, A.T. \& Hinkel, J., 2016. Household-Level Coastal Adaptation and Its Drivers: A Systematic Case Study Review. Risk Analysis, 37(4), pp.629-646. Available at: http://dx.doi.org/10.1111/risa.12663.

Law on critical infrastructures, 2019. Available at: https://www.zakon.hr/z/591/ Zakon-o-kritičnim-infrastrukturama, accessed on: July, 2019.
Law on the Safety of Maritime Ships and Ports of Republic of Croatia, 2019. Available at: https://www.zakon.hr/z/504/Zakon-o-sigurnosnoj-zaštiti-pomorskih-brodova-iluka., accessed on: July, 2019.

Leonhart, L.S. \& Hargis, D.R., 2005. Forensic Hydrogeology. Water Encyclopedia. Available at: http://dx.doi.org/10.1002/047147844x.sw323.

Lischeid, G. et al., 2016. Forensic hydrology: what function tells about structure in complex settings. Environmental Earth Sciences, 76(1). Available at: http://dx.doi. org/10.1007/s12665-016-6351-5.

Merriam Webster, 2019. Available at: https://www.merriam-webster.com/ dictionary/fishing, accessed on: September, 2019.

Ministry of the sea, transportation and infrastructure of Republic of Croatia, 2019. Available at: http://www.mppi.hr/default.aspx?id=477, accessed on: July, 2019.

NOAA's Coastal Zone Management, 2019. Available at: http://oceanservice.noaa. gov/facts/czm.html, accessed on: September, 2019.

Passeri, D.L. et al., 2015. The dynamic effects of sea level rise on low-gradient coastal landscapes: A review. Earth's Future, 3(6), pp.159-181. Available at: http://dx.doi. org/10.1002/2015ef000298.

Ramirez, A.I. \& Herrera, A., 2016. Forensic Hydrology. Forensic Analysis - From Death to Justice. Available at: http://dx.doi.org/10.5772/64616.

Spatial Data Infrastructure Cookbook v2.0, 2004. Available at: http://www.ths.org. uk/content.asp?page $=26$.

The European Maritime Safety Agency, 2019. Available at: http://www.emsa.europa. eu/, accessed on: September, 2019.

The International Hydrographic Organization, 2019. Available at: https://www.iho. int/srv1/index.php?lang=en, accessed on: September, 2019.

The International maritime organization, 2019. Available at: http://www.imo.org/ en/OurWork/safety/navigation/pages/enavigation.aspx, accessed on: September, 2019.

Van Schijndel, S.A.H. \& Kranenburg, C., 1998. Reducing the siltation of a river harbour. Journal of Hydraulic Research, 36(5), pp.803-814. Available at: http:// dx.doi.org/10.1080/00221689809498604.

Voulvoulis, N. \& Burgman, M.A., 2019. The contrasting roles of science and technology in environmental challenges. Critical Reviews in Environmental Science and Technology, 49(12), pp.1079-1106. Available at: http://dx.doi.org/10.1080/106 43389.2019.1565519.

Want, X.H. \& Andutta F.P., 2013. Sediment Transport Dynamics in Ports, Estuaries and Other Coastal Environments. Sediment Transport Processes and Their Modelling Applications. Available at: http://dx.doi.org/10.5772/51022.

Werner, A.D. et al., 2013. Seawater intrusion processes, investigation and management: Recent advances and future challenges. Advances in Water Resources, 51, pp.3-26. Available at: http://dx.doi.org/10.1016/j.advwatres.2012.03.004.

Witte, J.-P., Zaadnoordijk, W. \& Buyse, J., 2019. Forensic Hydrology Reveals Why Groundwater Tables in The Province of Noord Brabant (The Netherlands) Dropped More Than Expected. Water, 11(3), p.478. Available at: http://dx.doi.org/10.3390/ w11030478.

Žanić Mikuličić, J. et al., 2018. Distribucija pomorskih sigurnosnih informacija i mjere poboljšanja sigurnosti plovidbe. Naše more, 65(3), pp.164-168. Available at: http:// dx.doi.org/10.17818/nm/2018/3.6 